\title{
Control of bacterial production in cold waters. A theoretical analysis of mechanisms relating bacterial production and zooplankton biomass in Disko Bay, Western Greenland
}

\author{
T. Frede Thingstad ${ }^{1, *}$, Torkel Gissel Nielsen ${ }^{2}$, Anja Skjoldborg Hansen ${ }^{2}$, \\ Henrik Levinsen ${ }^{2, * *}$
}

\author{
${ }^{1}$ Department of Microbiology, University of Bergen, Jahnebakken 5, 5020 Bergen, Norway \\ ${ }^{2}$ Department of Marine Ecology, National Environmental Research Institute, PO Box 358, 4000 Roskilde, Denmark
}

\begin{abstract}
Data on planktonic bacterial production and biomass of copepods and heterotrophic dinoflagellates in Disko Bay, Greenland, are discussed within the framework of a theoretical model. The model is an extension of a previously published model that relates bacterial production and shifts between carbon and mineral nutrient limitation of bacteria to the structure of the planktonic food web. We suggest how dinoflagellates can be incorporated into this framework, and show how this affects bacterial production. With the parameters used, the model predicts the system mainly to be in, or close to, the state leading to carbon-limited bacterial growth, a prediction in accordance with results published for this environment. In the model, this is caused by a high combined biomass of copepods and heterotrophic dinoflagellates that keeps the biomass of phytoplankton competitors low and the regeneration rate high. In Disko Bay, high copepod biomass is not primarily the result of a succession from a high phytoplankton biomass to their predators, but is largely caused by migration of an over-wintering copepod population from deep waters into the photic zone prior to the spring bloom. The set of data thus comprises no situations combining high phytoplankton biomass with low combined biomass of heterotrophic dinoflagellates and copepods, a situation that in the model would lead to a state with pronounced mineral nutrient limitation of bacterial growth rate. Since such seasonal copepod migration is a feature common to many arctic ecosystems, the suggested relationship has strong potential implications for carbon cycling in the Arctic.
\end{abstract}

KEY WORDS: Bacterial growth $\cdot$ Polar $\cdot$ Food web models $\cdot$ Copepods

\section{INTRODUCTION}

Over the last 2 decades, many studies have focused on bacterial production in polar environments (see Rivkin et al. 1996 for review). These have often focused on the potential role of low temperature, suggested by Pomeroy \& Deibel (1986) to have a more negative effect on bacteria than on phytoplankton. Connected

\footnotetext{
*E-mail: frede.thingstad@im.uib.no

${ }^{* *}$ Present address: University of Copenhagen, Helsingørsgad 49-51, 3400 Hillerød, Denmark
}

to this is the debate as to whether low temperature is compensated by a higher substrate concentration (Pomeroy \& Wiebe 2001). The debate on this point is obviously hampered by our lack of understanding of how bacterial production in the pelagic zone is controlled in general. To some extent, the complexity of the problem can be illustrated by imagining an attempt to understand the effect of temperature on bacterial production in a laboratory chemostat. If we try to explain this from knowledge of bacterial physiology alone, we run into the problem that bacterial growth rate and biomass at steady state are determined by 
dilution rate and by concentration of the limiting substrate in the medium reservoir, respectively. What is needed in a food web context may thus be first to identify ecosystem properties that correspond to pump speed and reservoir nutrient concentration in the chemostat analogy, then to understand how these are affected by temperature. Direct temperature effects on bacterial physiology would then primarily be expected to be important if they change the efficiency by which organic substrates are converted to bacterial biomass. Further complicating the issue is the accumulating evidence that the pelagic food web may be in states leading to either mineral nutrient or carbon limitation of the heterotrophic bacteria (Rivkin \& Anderson 1997). Any deeper understanding of the effect of temperature would thus also seem to have to be integrated with an understanding of the mechanisms leading to these 2 states and to shifts between them.

Arctic ecosystems have many peculiarities other than direct effects of low temperature on growth rate of phytoplankton and bacteria. One characteristic is the change in light conditions and water column stratification caused by ice melting. In an environment such as the Barents Sea this can lead to a shallow mixed layer with an intense spring phytoplankton bloom depleting the surface layer for mineral nutrients (Sakshaug 1997). The conditions for potential mineral nutrient limitation of heterotrophic bacteria might therefore seem to be present, especially since the phytoplankton community in the Arctic often has a large component of Phaeocystis spp. producing large amounts of carbohydrates (Verity et al. 1991). The degradability of these carbohydrates has been debated (Thingstad \& Billen 1994), but recent work (Janse et al. 1999) supports the view that they are to a large extent accessible to bacterial degradation. Work trying directly to assess the type of limitation experienced by the bacteria in the stratified summer season in Disko Bay, Western Greenland, has, however, indicated that the bacteria in this environment were carbon limited, rather than mineral nutrient limited (Møller \& Nielsen 2000).

The special conditions of the Arctic also represent special challenges to the metazoan populations. The low generation times attainable for copepods and the need to be present to match the spring bloom may be some of the constraints that have led to the evolution of a behavioural pattern in which Calanus spp. store energy reserves during the short summer period in the surface layer and then migrate to deep waters for overwintering. Top-down effects on the photic zone food web may thus come from the invasion of a large copepod population, rather than as the result of a succession from free nutrients, via phytoplankton, to a buildup of the copepod population.
To our knowledge, the only model so far proposed for the mechanisms relating food web structure to shifts between carbon and mineral nutrient limited bacterial growth, is the model used by Thingstad et al. (1997) or any of its siblings (Thingstad \& Lignell 1997, Thingstad 2000). In these, algal-bacterial competition for mineral nutrients combined with bacterial predation allows a description of bacterial production and carbon demand in the mineral nutrient limited case. If this carbon demand cannot be met by autochthonous or allochthonous supply, the pool of carbon substrates must eventually become depleted, and the bacteria shift to carbon limitation. By adding a hypothesis for the mechanisms producing carbon substrates for bacterial growth, a framework is obtained within which both carbon and mineral nutrient limited bacterial production can be described.

We have here compared this type of model, slightly modified by including heterotrophic dinoflagellates, to data collected in Disko Bay.

\section{MATERIALS AND METHODS}

The data used here are a subset of data collected during investigations in Disko Bay, Western Greenland. In the ice-free period, the northern part of the bay is characterised by stable stratification and depletion of nitrate from the upper part of the water column. Only points with nitrate below the detection limit (0.06 $\mu$ mol- $\mathrm{N}^{-1}$ ) have been included in the present analysis. The equations derived also assume diatoms to be present and not silicate limited, although silicate concentration is reduced to $1 \mu \mathrm{mol} \mathrm{^{-1 }}$ during summer. Intuitively, one would expect Si limitation of diatoms to enhance bacterial carbon demand of mineral nutrient limited bacteria due to reduced competition from diatoms. Although the case with silicate limitation of diatoms thus is interesting, and can be modelled in a similar manner, it complicates the mathematical expressions considerably and is not considered here.

Data from 1994 and 1996 are included in the analysis. In 1994, data for bacterial production as well as total biomass and mesozooplankton biomass were available in the period 25 August to 15 September (Hansen et al. 1999, Levinsen et al. 1999, Nielsen \& Hansen 1999). In 1996, data were available in the period 19 May to 9 October for chlorophyll $a$, nutrients and bacterial production as well as biomass of heterotrophic nanoflagellates (T.G.N. et al. unpubl.), ciliates and heterotrophic dinoflagellates (Levinsen et al. 2000a) and copepods (Madsen et al. 2001). The total biomass is obtained by summing all organism groups measured. Fig. 1 shows depth and time of sampling points. 


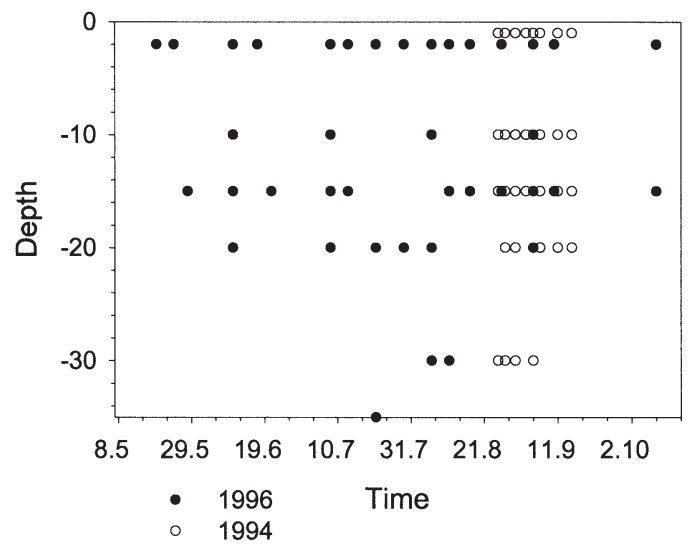

Fig. 1. Time and depth of data points with non-measurable nitrate in 1994 and 1996

\section{MODEL CONSIDERATIONS}

For mesocosm experiments with moderate perturbations, it has been suggested that descriptions based on assuming an idealised food web structure with the lower parts of the food web to be in internal steady state may provide a useful approximation to a complex reality (Thingstad et al. 1999a,b). We here use a similar approach based on the idealised food web structure outlined in Fig. 2. This is an extension of one of the alternative food webs discussed by Thingstad (Fig. 6 in Thingstad 2000). The added feature here is that we have split the common predator on diatoms and ciliates into a combination of heterotrophic dinoflagellates and copepods (Fig. 2). The reason for this split is that heterotrophic dinoflagellates and copepods have differences in behaviour, believed to be important in the regulation of the Disko Bay ecosystem. From a theoretical point of view, the idealised dinoflagellate-copepod relationship in Fig. 2 is also interesting, since the copepods in Fig. 2 represent another version of the 'strategy of eating one's competitor', previously analysed in detail for mixotrophic protists (Thingstad et al. 1996).

In such a food web, a fixed relationship between components occurs only if parts or all of the system has reached steady state. We want to focus on the possible relationship between bacterial production and the biomass of top predators: heterotrophic dinoflagellates $(Z)$ and copepods $(M)$ (symbols summarized in Table 1). In other words, we seek a relationship, via food web interactions, between the lower left and the upper right corner of the food web in Fig. 2. Such a fixed relationship between mineral nutrient limited bacterial production $\left(B P_{N}\right)$, and the top predators, $Z$ and $M$, can be derived if both the bacterial predator (heterotrophic flagellates, $H$ ) and the bacterial mineral nutrient competitors (autotrophic flagellates, $A$, and diatoms, $D$ ) are close to steady state. The formulation of this in mathematical terms is given in Appendix 1 for the simplified case where all food consumption rates are assumed to be proportional to food availability. Under this simplifying assumption the fixed relationship gives $B P_{N}$ as proportional to the square of the weighted sum $\rho Z+M$ (Eq. 8), where $\rho$ is the ratio between the clearance rates of heterotrophic dinoflagellates and copepods. Due to the multiplicative effect on biomass and growth rate, $B P_{N}$ becomes very sensitive to the amount of biomass in the top predators. The argument is the same as previously used in models with $B P_{N}$ proportional to the square of ciliate biomass used to interpret results from experimental micro- (Thingstad et al. 1999b) and mesocosms (Thingstad et al. 1999a). Since, in the model used here, ciliate biomass, $C$, is also proportional to $\rho Z+M$ (can be derived from Eq. 6 ), $B P_{N}$ could equivalently be expressed as proportional to $C^{2}$ in the present model.

The bacterial production $B P_{N}$ corresponds to bacterial carbon demand, $B P_{N} / Y_{B C}$, where $Y_{B C}$ is the bacterial yield coefficient on carbon substrates (for units see Table 1). If allochthonous + autochthonous supply of organic substrates for bacterial production cannot meet this carbon demand, the pool of labile dissolved organic carbon (DOC) will become depleted, and the bacterial carbon demand reduced until demand balances the supply of labile DOC. For a fixed $Y_{B C}$, bacterial production under carbon limitation must therefore be less than the potential value obtainable under mineral nutrient limitation (for a given value of $\rho Z+M$ ).

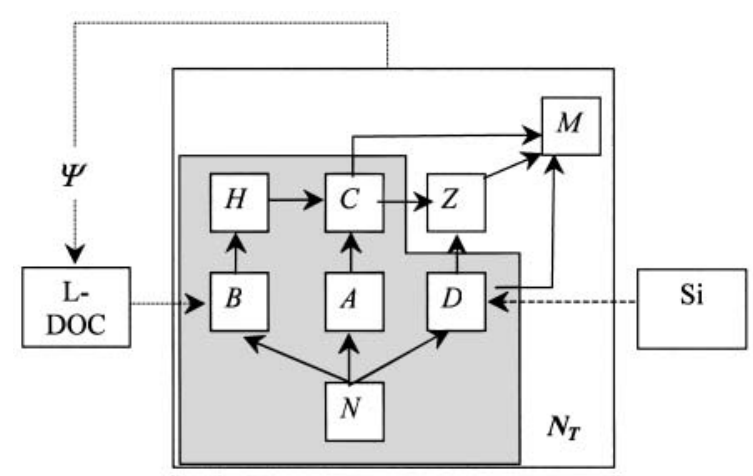

Fig. 2. Structure of the idealized food web analysed consisting of heterotrophic bacteria $(B)$, autotrophic $(A)$ and heterotrophic $(H)$ flagellates, diatoms $(D)$, ciliates $(C)$, heterotrophic dinoflagellates $(Z)$ and copepods $(M)$. The shaded area indicates the part of the system assumed to be in steady state. Autochthonous production, $\Psi$, of organic substrates for the bacteria is assumed to increase linearly with total content $\left(N_{\mathrm{T}}\right)$ of the limiting element $N$ in the system. Flows of the element $N$ are indicated by solid arrows, flows of organic carbon by dotted arrows. Dashed arrow indicates silicate input to diatoms. In the present analysis silicate is assumed to be nonlimiting and does not enter into the equations 
Table 1. Symbols used in our model. Asterisk used on symbols in text denotes steady state

\begin{tabular}{|c|c|c|}
\hline Symbol & Meaning & $\begin{array}{l}\text { Units (when measuring biomass } \\
\text { in nitrogen units) }\end{array}$ \\
\hline \multicolumn{3}{|c|}{ Variables retained in final model } \\
\hline$B P$ & \multirow{3}{*}{$\begin{array}{l}\text { Bacterial production, subscript } N \text { and } C \text { specify mineral nutrient and carbon } \\
\text { limited bacterial growth rate, respectively }\end{array}$} & 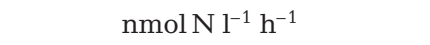 \\
\hline$B P_{N}$ & & \\
\hline$B P_{C}$ & & \\
\hline$Z$ & Heterotrophic dinoflagellates & $\mathrm{nmol} \mathrm{N} \mathrm{l^{-1 }}$ \\
\hline$M$ & Copepods & 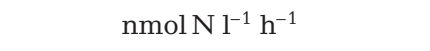 \\
\hline \multicolumn{3}{|c|}{ Variables eliminated by steady-state requirements } \\
\hline$N$ & Free mineral nutrient & $\mathrm{nmol} \mathrm{N} \mathrm{l^{-1 }}$ \\
\hline$B$ & Heterotrophic bacteria & $\mathrm{nmol} \mathrm{N} \mathrm{l^{-1 }}$ \\
\hline$A$ & Autotrophic flagellates & $\mathrm{nmolN} \mathrm{l}^{-1}$ \\
\hline$D$ & Diatoms & $\mathrm{nmol} \mathrm{N} \mathrm{l} \mathrm{l}^{-1}$ \\
\hline$H$ & Heterotrophic flagellates & $\mathrm{nmol} \mathrm{N} \mathrm{l}^{-1}$ \\
\hline$C$ & Ciliates & $\mathrm{nmol} \mathrm{N} \mathrm{l}^{-1}$ \\
\hline \multicolumn{3}{|c|}{ Parameters retained in final model } \\
\hline$k_{1}$ & Combined parameter $\frac{\alpha_{B} \alpha_{A}}{Y_{H} \alpha_{H}}\left(\frac{\alpha_{M}}{\alpha_{D}}\right)^{2}$ & $\operatorname{lnmol~N}{ }^{-1} h^{-1}$ \\
\hline$k_{2}$ & Proportionality constant between total biomass and $B P_{C}$ & $\mathrm{~h}^{-1}$ \\
\hline$\rho$ & Combined parameter $\alpha_{Z} / \alpha_{M}$ & Dimensionless \\
\hline \multicolumn{3}{|c|}{ Parameters eliminated } \\
\hline$\alpha_{B}$ & Bacterial affinity constant for $N$ & $\operatorname{lnmolN} N^{-1} h^{-1}$ \\
\hline$\alpha_{A}$ & Autotrophic flagellate affinity for $N$ & $\operatorname{lnmol~N}{ }^{-1} h^{-1}$ \\
\hline$\alpha_{D}$ & Diatom affinity for $N$ & $\operatorname{lnmol~N}{ }^{-1} h^{-1}$ \\
\hline$\alpha_{H}$ & Heterotrophic flagellate clearance rate for $B$ & $\operatorname{lnmol~N}{ }^{-1} h^{-1}$ \\
\hline$\alpha_{C}$ & Ciliate clearance rate for $A$ and $H$ & $\operatorname{lnmol~N}{ }^{-1} h^{-1}$ \\
\hline$\alpha_{Z}$ & Heterotrophic dinoflagellate clearance rate for $D$ and $C$ & $\operatorname{lnmol~N}{ }^{-1} h^{-1}$ \\
\hline$\alpha_{M}$ & Copepod clearance rate for $D, C$, and $Z$ & $\operatorname{lnmol~N}{ }^{-1} h^{-1}$ \\
\hline$Y_{H}$ & Fraction of nitrogen in prey $(B)$ incorporated into heterotrophic flagellates $(H)$ & Dimensionless \\
\hline
\end{tabular}

An increased yield, i.e. more bacteria produced per unit of organic material consumed under carbon limitation, could partially compensate to give a smaller reduction. In a set of data containing situations with both carbon and mineral nutrient limited bacteria, a log-log plot of bacterial production versus $\rho Z+M$ should from this argument have as an upper envelope a straight line with slope 2. Points on this line should correspond to situations with mineral nutrient limited bacteria. All points below this line should correspond to carbon limited bacterial growth.

In the case of carbon limited bacterial growth, bacterial production is linked to the supply rate, $\Psi$, of organic substrates so that $B P_{C}=Y_{B C} \Psi$. Constructing a detailed model for $\Psi$ involving mechanisms such as active and passive production by phytoplankton, sloppy feeding, viral lysis, etc., would give a more complex model than wanted for our present purpose. We have here chosen a simple proportionality $B P_{C}=k_{2} N_{\mathrm{T}}$ [corresponding to $\Psi=\left(k_{2} / Y_{B C}\right) N_{\mathrm{T}}$ ] to reflect the broad assumption that there is a general positive correlation between biomass in the system and its production of carbon substrates for the bacteria.

Since the actual bacterial production $(B P)$ that can be realised in a given situation is the smallest one of $B P_{N}$ and $B P_{C}$, we get the general formula: $B P=\min \left(B P_{N}\right.$, $\left.B P_{C}\right)$ or $B P=\min \left[k_{1}(\rho Z+M)^{2}, k_{2} N_{\mathrm{T}}\right]$. We thus have a 3parameter $\left(k_{1}, k_{2}\right.$, and $\left.\rho\right)$ model suggested to explain bacterial production from 3 measurable variables: total nutrients $\left(N_{\mathrm{T}}\right)$, biomass of heterotrophic dinoflagellates $(Z)$, and biomass of copepods $(M)$. As $Z$ and $M$ are parts of $N_{\mathrm{T}}$, we also have the condition $Z+M<N_{\mathrm{T}}$.

\section{NUMERICAL VALUES OF PARAMETERS AND COMPARISON TO DATA}

The $k_{1}$ parameter is a function of the parameters describing properties of organisms in the food web, given by the theoretical expression (Appendix 1): 


$$
k_{1}=\frac{\alpha_{B} \alpha_{A}}{Y_{H} \alpha_{H}}\left(\frac{\alpha_{M}}{\alpha_{D}}\right)^{2}
$$

Although the model is based on lumping species with different characteristics into idealised functional groups, it is still possible to get some ideas on the expected magnitude of $k_{1}$. Theoretical maximum values for the affinity constants for the osmotrophs can be estimated from diffusion considerations (Jumars et al. 1993) according to the formula $3 D / \sigma r^{2}$. Here, $D$ is the diffusion constant in water of the common limiting mineral nutrient, $\sigma$ is the volume-specific content of the element in the organism, and $r$ is the radius of the assumed spherical organism (Thingstad \& Rassoulzadegan 1999). Inserting this, the dimensionless ratio of osmotroph affinities in the expression for $k_{1}$ becomes

$$
\frac{\alpha_{B} \alpha_{A}}{\alpha_{D}^{2}}=\frac{\sigma_{D}^{2}}{\sigma_{A} \sigma_{B}} \frac{r_{D}^{2}}{r_{A} r_{B}}
$$

It has been argued (Aksnes \& Egge 1991, Thingstad \& Rassoulzadegan 1999) that, while in general diatoms are larger than autotrophic flagellates $\left(r_{D}>r_{A}\right)$, their vacuole may allow them to have a smaller volumespecific content of the limiting element $\left(\sigma_{D}<\sigma_{A}\right)$. For bacteria, the case is the opposite, although in general they are smaller $\left(r_{B}<r_{A}\right)$, their low $\mathrm{C}: \mathrm{N}$ ratio and in particular their low C:P ratio, (Fagerbakke et al 1996) and possibly a high C:volume content (Bratbak \& Dundas 1984, Bratbak 1985) suggest that $\sigma_{B}>\sigma_{A}$. If we assume a 1:5:25 ratio in $r_{B}: r_{A}: r_{D}$, corresponding to radii of, for example, $0.4,4$, and $10 \mu \mathrm{m}$, the dimensionless factor caused by size differences among the osmotrophs becomes

$$
\frac{r_{D}^{2}}{r_{A} r_{B}} \approx 125
$$

Assuming a hypothetical spherical diatom with radius $10 \mu \mathrm{m}$ and a $1 \mu \mathrm{m}$ thick cytoplasm layer along the wall, the cytoplasm volume will occupy $19 \%$ of the cell volume. Assuming the vacuole to be free of the limiting element and the cytoplasm to have the same volume-specific content in autotrophic flagellates and in diatoms, $\sigma_{D} \approx 0.2 \sigma_{A}$. Combining the assumption that bacteria seem to have a somewhat higher C:volume ratio than protists and also a slightly higher $\mathrm{C}: \mathrm{N}$ ratio, we have assumed $\sigma_{B} \approx 2 \sigma_{A}$. The dimensionless factor caused by different specific nutrient content in the osmotrophs then becomes

$$
\frac{\sigma_{D}^{2}}{\sigma_{A} \sigma_{B}} \approx 0.02
$$

With the precision obtainable in these estimates, the combined factor representing the effect of osmotroph properties obtained from multiplying these 2 factors is thus around 2.5 .
Heterotrophic flagellates have been reported to have a clearance rate up to $10^{6}$ times their own body volume per hour (Fenchel 1982). Assuming a protist C:volume

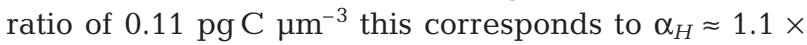
$10^{-4} 1 \mathrm{nmol} \mathrm{C}^{-1} \mathrm{~h}^{-1}$.

Using a maximum clearance rate for large copepods of $2.58 \times 10^{-6} \mathrm{lnmol} \mathrm{C} \mathrm{n}^{-1} \mathrm{~h}^{-1}$ (corrected to ${ }^{\circ} \mathrm{C}$ ) (Levinsen et al. 2000b) and an assumed efficiency in the transfer of $\mathrm{N}$ from bacteria to heterotrophic flagellates of 0.3 , we get the dimensionless ratio containing the effect from the predators, $\alpha_{M} / Y_{H} \alpha_{H} \approx$ 0.08 . Finally, this gives us an estimated $k_{1} \approx 2.5 \times$ $0.08 \alpha_{M}=5 \times 10^{-7} 1 \mathrm{nmol} \mathrm{C}^{-1} \mathrm{~h}^{-1}$ or, in nitrogen units, $3.3 \times 10^{-6} 1 \mathrm{nmolN}^{-1} \mathrm{~h}^{-1}$, using a $\mathrm{C}: \mathrm{N}$ ratio in copepods of 106:16.

Since our model for labile DOC production by the system is very crude, we are unable to estimate $k_{2}$ from theoretical considerations. The value of $k_{2}=$ $0.0008 \mathrm{~h}^{-1}$ is obtained from fitting a straight line to the data set. The simple relationship $B P=k_{2} N_{\mathrm{T}}$ explains $58.5 \%$ of the variation in observed bacterial production.

Based on literature data for dinoflagellates and copepods (Hansen et al. 1997, Levinsen et al. 2000b), we have initially used a value of 1.7 for $\rho$. The range in observed data is however large.

Fig. 3 shows the shape of the response surface with these parameter values, the effect of reducing $k_{1}$ or $k_{2}$ by $50 \%$, and the effect of changing from a linear to a quadratic relationship between total biomass and carbon limited bacterial production. The requirement of $Z+M<N_{\mathrm{T}}$ cannot be properly represented in these plots, but is approximated by setting $B P=0$ for $\rho Z+M>N_{\mathrm{T}}$.

With $k_{2}$ estimated from the data, and $k_{1}=3.3 \times 10^{-6} 1$ nmol $\mathrm{N}^{-1} \mathrm{~h}^{-1}$ and $\rho=1.7$ obtained as described above, the model explains $54 \%$ of the variation in bacterial production. Fitting all 3 parameters by minimising the sum of squared distances to the surface of Fig. 3A gave $k_{1}=2.4 \times 10^{-6} 1 \mathrm{nmolN}^{-1} \mathrm{~h}^{-1}, k_{2}=0.00096 \mathrm{~h}^{-1}$ and $\rho=$ 3.4. The main difference from the original set of parameters is a doubling in $\rho$. This change in $\rho$ is within the range of observations. With all 3 parameters fitted, the model accounts for $58.2 \%$ of the variance in observed bacterial production.

The fitted response surface with experimental points is shown in Fig. 4. Points close to the origin correspond to the late summer season, when copepods have migrated out of the photic zone. Points with high bacterial production correspond to early season. Points close in the region corresponding to mineral nutrient limited bacterial growth are in the late season, when copepods had left the photic zone, leaving a small combined biomass of copepods. 

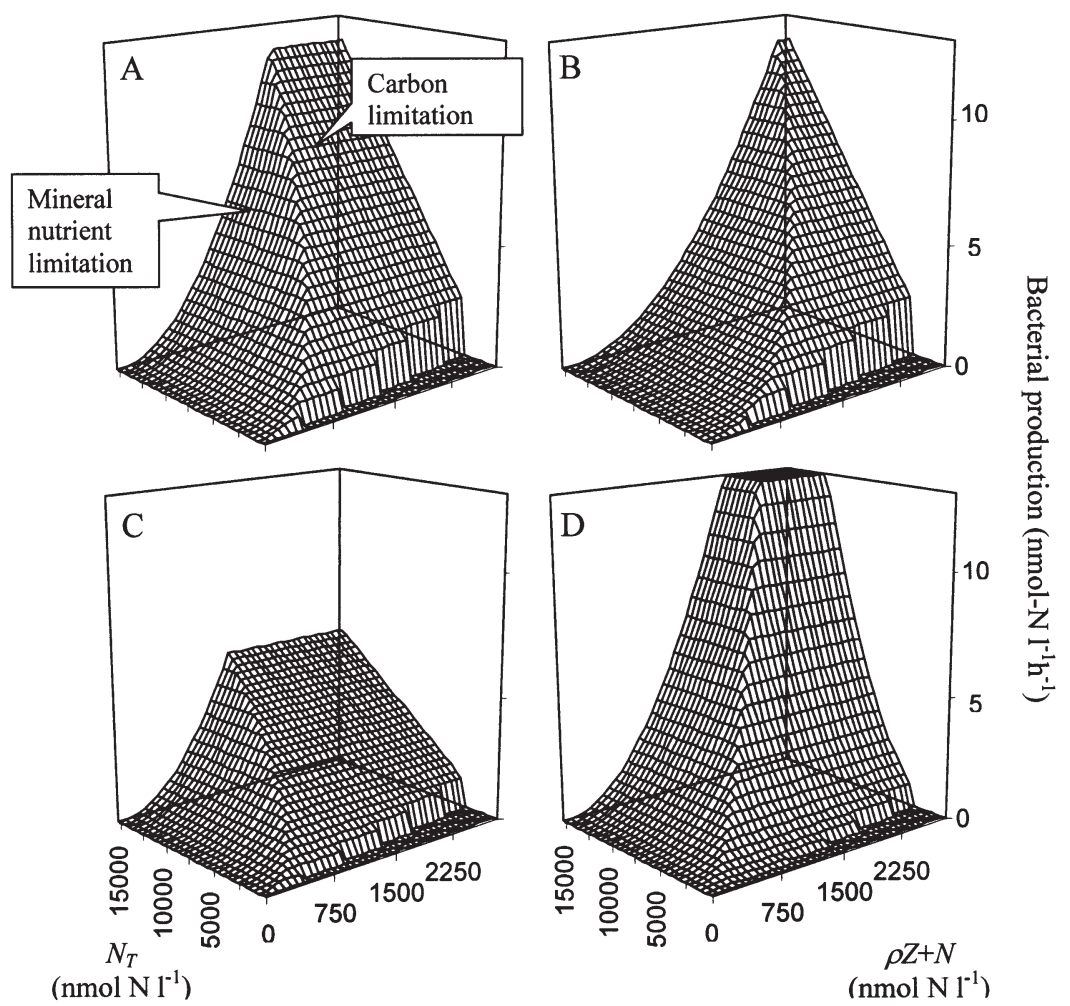

Fig. 3. Theoretical response surface of bacterial production as a function of the weighted sum of dinoflagellate and copepod biomass $(\rho Z+M)$, and the total nutrient concentration $\left(N_{\mathrm{T}}\right)$ in the system. (A) Linear relationship between carbon-limited bacterial production and total biomass and the parameter values used in the text; (B) $k_{1}$ or (C) $k_{2}$ reduced by $50 \%$; and (D) carbon limited bacterial production proportional to the square of total biomass $\left(B P_{C}=1 \times 10^{-7} N_{\mathrm{T}}^{2}\right)$

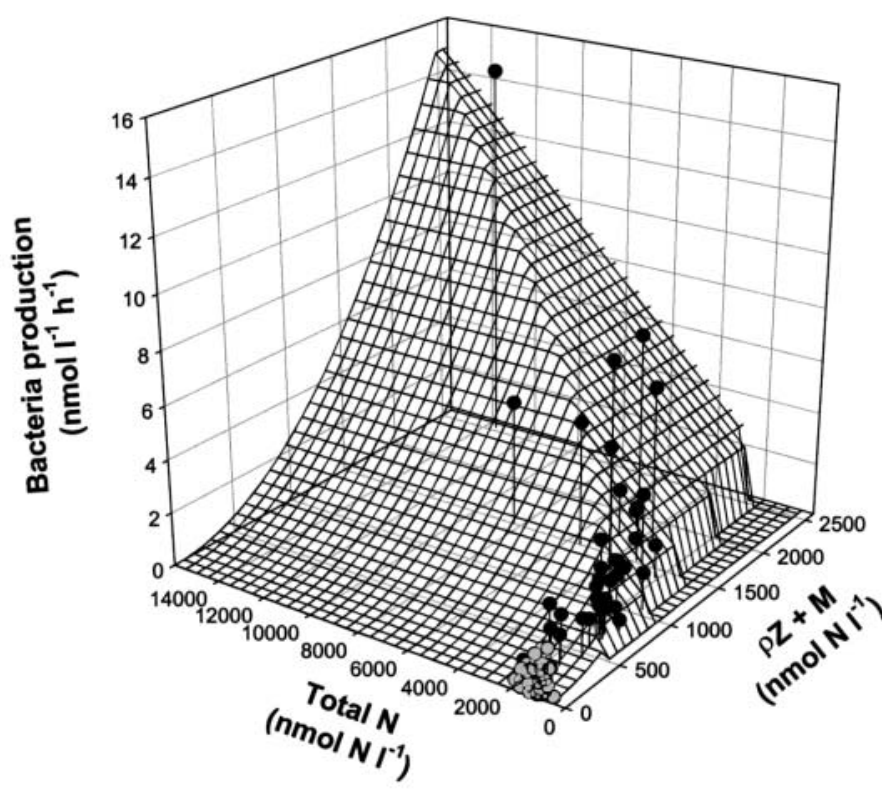

Fig. 4. Theoretical response surface of bacterial production as a function of the weighted sum of dinoflagellate and copepod biomass $(\rho Z+M)$, and the total nutrient concentration in the system $\left(N_{\mathrm{T}}\right)$ using fitted parameters $\rho=3.4, k_{1}=2.4 \times 10^{-6} 1$ nmol N ${ }^{-1} \mathrm{~h}^{-1}$, and $\mathrm{k}_{2}=9.6 \times 10^{-4} \mathrm{~h}^{-1}$. Compared to measured data points from 1994 (grey) and 1996 (black)

\section{DISCUSSION}

We would argue that the general picture suggested by Fig. 4 may be more robust than what one perhaps could suspect from the simplicity of the arguments used to derive it. Disregarding the exact shape of the response surface, what Fig. 4 in broad terms implies is as follows:

- The more biomass there is in the system, the more degradable organic material is produced.

- There is an upper limit to bacterial production on such material, given by the biomass and growth rate obtainable under conditions of mineral nutrient limited bacterial growth.

- This upper limit increases with the amount of predators since these 'speed up' the system by removing osmotroph biomass and recycle the limiting nutrient. As is obvious from Fig. 3A to $\mathrm{C}$, the uncertainty in parameter estimation and in the relationship between carbon limited bacterial production and total biomass makes it impossible to identify with any great precision the border-line between carbon and mineral nutrient limited bacterial growth. However, with $k_{1}$ and $\rho$ obtained from theoretical considerations and from litera- 
ture data, as well as when all 3 parameters were obtained from maximising the fit of the model to the data, most points fall in, or close to, the region of carbon limited bacterial growth (Fig. 4). The reason for this is that all points in the available data set are characterised by a relatively high ratio between the biomass in top predators and the total biomass. The high biomass of top predators in the Disko Bay ecosystem is a consequence of the behavioural pattern of hibernating copepods migrating from deep waters into the photic zone before the spring bloom (Madsen et al. 2001). If, instead, copepod biomass build-up had come as the result of a succession from mineral nutrients, via phytoplankton, to copepods, one would expect the middle part of such a succession to have points characterised by most of the initially available nutrients tied up in phytoplankton biomass. Such a situation would imply high biomass of mineral nutrient competitors and little recycling of mineral nutrients from their predators, promoting mineral nutrient limited bacteria as described more formally by the mathematical model.

Points close to or in the region of mineral nutrient limited bacterial growth rate are primarily found in late season (August and September in 1994 and 1996), when both the top predator and the total biomass are low because copepods had left the surface layer.

With the emphasis put on copepods and heterotrophic dinoflagellates in this model, it is tempting to describe mineral nutrient limited bacterial production as strongly top-down controlled. Note, however, that the squared effect of top predator biomass on bacterial production comes from the multiplication of biomass, controlled via bacterial predators, and growth rate, controlled via bacterial competitors (phytoplankton). 'Top-down' and 'bottom-up' controls are thus not independent phenomena in food webs of the type discussed here.

We have linked bacterial production to biomass of heterotrophic dinoflagellates and copepods in an algebraic relationship (Eq. 8). Such a fixed algebraic relationship can in general only be expected if the food web that links the two is close to internal steady state. Eq. (8) would still be valid if the steady state had evolved further to include also the heterotrophic dinoflagellates $(Z)$, and also if it included both these and the copepods $(M)$. By including $Z$ in the steady state part of the food web, one would gain the advantage that the equilibrium value of $Z$ in terms of $M$ and $N_{\mathrm{T}}$ can be calculated. $Z$ could then be eliminated from the expression for mineral nutrient limited bacterial production. The equations (not shown) predict a negative correlation between $Z$ and $M$, which is what we find also in this data set when the large Calanus spp. have left the photic zone $\left(Z=-0.05 M+181, \mathrm{r}^{2}=0.16\right)$. Leaving Eq. (8) with $Z$ and $M$ as independent variables is, however, more general, and still gives a relationship between variables $\left(B P_{N}, Z\right.$, and $\left.M\right)$ that represents idealised, but still recognisable and measurable, biological entities.

The spread of experimental points around the assumed linear relationship between bacterial production and total biomass is relatively large. For a more precise model, one would probably need to take into account more detail in the structure, and maybe even the species composition of the food web. Since transfer rates in Lotka-Volterra formulations are present as the product of the concentrations of food and the consuming population, one might also speculate that production of organic substrates could scale more as the second than as the first power of biomass assumed here. As demonstrated in Fig. 3C, a squared relationship could change the response surface to include more points combining high total biomass and high biomass of top predators into the area of mineral nutrient limited bacterial growth. Such situations correspond to the spring bloom period in Disko Bay, with high bacterial production. Some of these points could therefore also be argued to possibly have been close to or in the state with mineral nutrient limited bacteria. A more precise model may turn out not to be feasible using aggregated variables such as total nutrient content or biomass. If such material is released differently by different species in the same functional groups, and if production is linked more to some processes and groups in the food web than to others, many more variables may be required as predictors for the mechanisms summing up to give the rate of production $(\Psi)$ of organic substrates for bacterial growth.

The model structure of Fig. 2 is not designed specifically for cold water environments, but is believed to be an idealisation with fairly general validity. Stated in another manner, any effect of temperature on the internal balance in this system may be a result of temperature effects on the parameters of the model, rather than a result of fundamental changes in its structure. This leads to some interesting consequences. The effect of the balance between osmotroph affinity constants on the compound parameter $k_{1}$ was given by the dimensionless ratio:

$$
\frac{\alpha_{B}}{\alpha_{D}} \frac{\alpha_{A}}{\alpha_{D}}
$$

If diffusion processes as assumed in our calculations really determine affinities, the temperature effect would be from changes in the viscosity of water (Jumars et al. 1993). The effect would be proportional in all affinity constants, and therefore cancel out. Should temperature somehow change mean size of the organisms in each functional group, or their volumespecific content of the common limiting element (more subtle, but presently unpredictable), net effects on the 
ratio between affinities could occur. The easiest assumption at present seems to be that temperature effects on mineral nutrient affinities cancel out in the steady-state situation of this model. Similarly, the ratios

$$
\frac{\alpha_{M}}{Y_{H} \alpha_{H}}
$$

and $\rho=\alpha_{Z} / \alpha_{M}$ would probably not be particularly sensitive to temperature. The main effect on $k_{1}$ would then scale as the effects on the copepod clearance rate, $\alpha_{M}$, i.e. with a $Q_{10}$ of approximately 2.8 (Hansen et al. 1997).

The combined parameter $k_{2} / Y_{B C}$ relates production of organic substrates for bacterial growth to total biomass in the system. Since the mechanisms behind production of labile DOC are not specified, the temperature influence on $k_{2}$ seems difficult to predict within the framework of the present model. In the Disko Bay ecosystem, zooplankton grazing has been suggested to be a main source of organic bacterial substrates (Møller \& Nielsen 2000). In a recent review, Nagata (2000) suggests that grazers, in particular protozoa, are the main contributors to the production labile DOC. It is not immediately obvious that temperature would have any major effect on the fraction of ingested material released during grazing.

Since most of the experimental points fall in the area where carbon-limited growth is predicted, the data available cannot be used to critically test the validity of the model's predictions for when mineral nutrient limited growth should be encountered. Several of the recent claims of mineral nutrient limited bacterial growth seem to link this to oligotrophic areas such as the Sargasso Sea (Cotner et al. 1997, Rivkin \& Anderson 1997) and the Mediterranean (Zohary \& Robarts 1998). The implication of our model would be that these areas should have low combined biomass of heterotrophic dinoflagellates and copepods, a prediction that would seem reasonable for oligotrophic regions.
We fully recognise that the model used here leaves many questions unanswered. The most serious is perhaps the validity of the very crude assumption that production of organic substrates for bacterial growth can be predicted from total biomass alone. Another is the validity of the steady-state assumption. Steady state in the microbial part implies that perturbations to the system must be so small or so infrequent that the microbial part (up to heterotrophic dinoflagellates) has approached internal equilibrium at the time when samples were taken. The time needed for relaxation of the system after a wind event or other types of perturbation could also be argued to increase as biological processes slow down at low temperature. To analyse this, however, a dynamic version of the model with fewer steady state assumptions would be needed.

Such refinements of the model are not expected to alter what we feel is the main message from this analysis: an understanding of possible differences between the control of bacterial production in polar and temperate waters requires a more profound understanding of ecosystem functioning, rather than only an understanding of how bacterial and algal physiology respond to low temperature. If the prediction of this model of dominantly carbon limited bacterial growth is correct, it is the system's autochthonous production rate of degradable organic substrates that is the key controlling factor for bacterial production (Thingstad \& Lignell 1977). A mechanism that leads to low bacterial affinity for these substrates at low temperature would produce a steady state characterised by a high substrate concentration, not by low bacterial carbon demand.

Acknowledgements. The authors wish to thank Birgit Søborg for technical assistance. The study was supported by The Danish National Research Council projects no. 9501038, 9700224 and 97001196 . A.S.H. was supported by The Danish Research Agency and by NORFA (grant no. 000487 to T.F.T. and B. Riemann)

Appendix 1. Relationship between biomass of top predators and bacterial production. Assumptions include Lotka-Volterra type equations for the trophic interactions and steady-state considerations in the idealised food web of Fig. 1. See Table 1 for symbols

Assuming diatoms to be in steady state (growth = sum of losses) we must have

$$
\alpha_{D} N^{*} D^{*}=\alpha_{Z} D^{*} Z+\alpha_{M} D^{*} M
$$

Setting $\alpha_{Z}=\rho \alpha_{M}$ and assuming diatoms to be present $\left(D^{*}>0\right), D^{*}$ can be eliminated to give the steady-state concentration of free mineral nutrient, $N^{*}$ :

$$
N^{*}=\frac{\alpha_{M}}{\alpha_{D}}(\rho Z+M)
$$

When diatoms are present and in steady state, the concentration of free mineral nutrients is thus linked to the biomass of higher predators. The growth rates of all mineral nutrient limited populations are thus also linked to the bio- mass of the top predator. When $D$ is in steady state, mineral nutrient limited bacterial growth rate $\mu_{N}=\alpha_{B} N$ is therefore a function of $Z$ and $M$ :

$$
\mu_{N}^{*}=\alpha_{B} \frac{\alpha_{M}}{\alpha_{D}}(\rho Z+M)
$$

Assuming steady state for the heterotrophic flagellates,

$$
Y_{H} \alpha_{H} B^{*} H^{*}=\alpha_{C} H^{*} C^{*}
$$

In the same terminology as before, bacterial biomass at steady state is thus linked to ciliate biomass $C^{*}$ :

$$
B^{*}=\frac{\alpha_{C}}{Y_{H} \alpha_{H}} C^{*}
$$


Appendix 1. (continued)

If, finally, the autototrophic flagellates are in steady state,

$$
\alpha_{A} N^{*} A^{*}=\alpha_{C} A^{*} C^{*}
$$

This relates ciliates to $N^{*}$ and thus to $Z$ and $M$. Insertion into Eq. (5) then gives

$$
B^{*}=\frac{\alpha_{A}}{Y_{H} \alpha_{H}} \frac{\alpha_{M}}{\alpha_{D}}(\rho Z+M)
$$

Since bacterial production is the product of growth rate and biomass, insertion from Eqs (3) \& (7) gives

$$
B P_{N}^{*}=k_{1}(\rho Z+M)^{2}
$$

where

$$
k_{1}=\frac{\alpha_{B} \alpha_{A}}{Y_{H} \alpha_{H}}\left(\frac{\alpha_{M}}{\alpha_{D}}\right)^{2}
$$

For carbon limited bacterial growth rate we assume

$$
B P_{C}^{*}=k_{2} N_{T}
$$

Bacterial production $B P^{*}$ cannot exceed the minimum of $B P_{N}^{*}$ and $B P_{C}^{*}$ :

$$
B P^{*}=\min \left(B P_{C}^{*}, B P_{N}^{*}\right)
$$

\section{LITERATURE CITED}

Aksnes D, Egge J (1991) A theoretical model for nutrient uptake in phytoplankton. Mar Ecol Prog Ser 70:65-72

Bratbak G (1985) Bacterial biovolume and biomass estimations. Appl Environ Microbiol 49:1488-1493

Bratbak G, Dundas I (1984) Bacterial dry matter content and biomass estimations. Appl Environ Microbiol 48:755-757

Cotner JB, Ammerman JW, Peele ER, Bentzen E (1997) Phosphorus-limited bacterioplankton growth in the Sargasso Sea. Aquat Microb Ecol 13:141-149

Fagerbakke K, Heldal M, Norland S (1996) Content of carbon, nitrogen, oxygen, sulfur and phosphorus in native aquatic and cultured bacteria. Aquat Microb Ecol 10:15-27

Fenchel T (1982) Ecology of heterotrophic microflagellates. II. Bioenergetics and growth. Mar Ecol Prog Ser 8:225-223

Hansen BW, Nielsen TG, Levinsen H (1999) Plankton community structure and carbon cycling on the western coast of Greenland during the stratified summer situation. III. Mesozooplankton. Aquat Microb Ecol 16:233-249

Hansen PJ, Bjørnsen PK, Hansen BW (1997) Zooplankton grazing and growth: scaling within the $2-2000-\mu \mathrm{m}$ body size range. Limnol Oceanogr 42:687-704

Janse I, van Rijssel M, Ottema A, Gottschal J (1999) Microbial breakdown of Phaeocystis mucopolysaccharides. Limnol Oceanogr 44:1447-1457

Jumars PA, Deming JW, Hill PS, Karp-Boss L, Yager PL, Dade BW (1993) Physical constraints on marine osmotrophy in an optimal foraging context. Mar Microb Food Webs 7:121-159

Levinsen H, Nielsen, TG, Hansen, BW (1999) Plankton community structure and carbon cycling on the western coast of Greenland during the stratified summer situation. II. Heterotrophic dinoflagellates and ciliates. Aquat Microb Ecol 16:217-232

Levinsen H, Nielsen TG, Hansen BW (2000a) Annual succession of marine pelagic protozoans in Disko Bay, West Greenland, with emphasis on winter dynamics. Mar Ecol Prog Ser 206:119-134

Levinsen H, Turner JT, Nielsen TG, Hansen BW (2000b) On the trophic coupling between protists and copepods in arctic marine ecosystems. Mar Ecol Prog Ser 204:65-77

Madsen SD, Nielsen, TG, Hansen BW (2001) Annual population development and production by Calanus finmarchicus, C. glacialis and C. hyperboreus in Disko Bay, Western Greenland. Mar Biol 138(6):1121-1130

Møller EF, Nielsen TG (2000) Plankton community structure and carbon cycling off the western coast of Greenland, with emphasis on sources of DOM for the bacterial community. Aquat Microb Ecol 22:13-25
Nagata T (2000) Production mechanisms of dissolved organic matter In: Kirchman D (ed) Microbial ecology of the oceans. Wiley-Liss, New York, p 121-152

Nielsen TG, Hansen BW (1999) Plankton community structure and carbon cycling on the western coast of Greenland during the stratified summer situation. I. Hydrography, phytoplankton and bacterioplankton. Aquat Microb Ecol 16:205-216

Pomeroy LR, Deibel D (1986) Temperature regulation of bacterial activity during the spring bloom in Newfoundland coastal waters. Science 233:359-361

Pomeroy LR, Wiebe WJ (2001) Temperature and substrates as interactive limiting factors for marine heterotrophic bacteria. Aquat Microb Ecol 23:187-204

Rivkin RB, Anderson MR (1997) Inorganic nutrient limitation of oceanic bacterioplankton. Limnol Oceanogr 42:730-740

Rivkin RB, Anderson MR, Lajzerowicz C (1996) Microbial processes in cold oceans. 1. Relationship between temperature and bacterial growth rate. Aquat Microb Ecol 10: 243-254

Sakshaug E (1997) Biomass and productivity distributions and their variability in the Barents Sea. ICES J Mar Sci 54: 341-350

Thingstad TF (2000) Control of bacterial growth in idealised food webs. In: Kirchman DL (ed) Microbial ecology of the ocean. John Wiley \& Sons, Inc, New York, p 229-259

Thingstad TF, Billen G (1994) Microbial degradation of Phaeocystis material in the water column. J Mar Syst 5: 55-65

Thingstad TF, Lignell R (1997) A theoretical approach to the question of how trophic interactions control carbon demand, growth rate, abundance, and diversity. Aquat Microb Ecol 13:19-27

Thingstad TF, Rassoulzadegan F (1999) Conceptual models for the biogeochemical role of the photic zone food web, with particular reference to the Mediterranean Sea. Prog Oceanogr 44:271-286

Thingstad TF, Havskum, H, Garde K, Riemann B (1996) On the strategy of 'eating your competitor'. A mathematical analysis of algal mixotrophy. Ecology 77:2108-2118

Thingstad TF, Hagstrøm ^, Rassoulzadegan F (1997) Export of degradable DOC from oligotrophic surface waters: caused by a malfunctioning microbial loop? Limnol Oceanogr 42:398-404

Thingstad TF, Havskum H, Kaas H, Lefevre D, Nielsen TG, Riemann B, Williams PJleB (1999a) Bacteria-protist interactions and organic matter degradation under P-limited conditions. Comparison between an enclosure experiment and a simple model. Limnol Oceanogr 44:62-79 
Thingstad TF, Pérez M, Pelegri S, Dolan J, Rassoulzadegan F (1999b) Trophic control of bacterial growth in microcosms containing a natural community from northwest Mediterranean surface waters. Aquat Microb Ecol 18:145-156 Verity PG, Smayda TJ, Sakshaug E (1991) Photosynthesis,

Editorial responsibility: Otto Kinne (Editor), Oldendorf/Luhe, Germany excretion, and growth rates of Phaeocystis colonies and solitary cells. Polar Res 10:117-128

Zohary T, Robarts RD (1998) Experimental study of microbial $\mathrm{P}$ limitation in the eastern Mediterranean. Limnol Oceanogr 43:387-395

Submitted: April 24, 2001; Accepted: September 25, 2001 Proofs received from author(s): February 4, 2002 